\title{
The headmaster's management strategy to handle the teachers' work stress at faza islamic primary school palembang
}

\author{
Putri Dian Sari ${ }^{1}$, Edi Harapan ${ }^{2}$, Yenny Puspita ${ }^{3}$ \\ ${ }^{1}$ SD Islam Faza Palembang \\ ${ }^{2}$ Universitas PGRI Palembang
}

\begin{tabular}{l}
\hline Article Info \\
\hline Article history: \\
Received Jul $13^{\text {th }}, 2021$ \\
Revised Aug $19^{\text {th }}, 2021$ \\
Accepted Aug $30^{\text {th }}, 2021$ \\
\hline
\end{tabular}

\section{Keyword:}

Strategies

Principal

Work Stress

\begin{abstract}
The aim of this research is to determine the principal's management strategy in dealing with teacher work stress. The research method using qualitative method with a descriptive approach. This research uses observation, in-depth interviews, and documentation to gather the data. Research subjects are the principal and teachers of Faza Islamic Elementary School Palembang. The results of research showed that the principal can implement three strategies in dealing with teacher work stress, so it does not interfere with teacher performance, the comfort of students, and does not hinder the school to achieve its goals. The strategies applied by the principal are 1) recognizing the symptom of teacher work stress, 2) identifying the emergence of work stress, 3) solve the problem as a result of work stress, then the principal deal with teacher work stress. This problem solving consist of three approaches, 1) through a personal approach, 2) a religious approach, 3) an official approach.
\end{abstract}

\section{Corresponding Author:}

Putri Dian Sari

SD Islam Faza Palembang

Email: putridiansari555@yahoo.co.id

\section{Introduction}

The teacher's formidable task, such as teach at school make them experience stress. It can be recognizes by interview and individual counseling results with teachers at Faza Islamic Elementary School Palembang who experienced stress and the teachers have to teach by long distance learning also resulting in stress. It was confirmed by the principal that some teachers experience stress and become susceptible to stress. And the researcher interested in conducting research on the causes of work stress.

Considers that work stress can have a positive effect (eustress) which is needed to produce high achievement, but in general, it harmful to the employees and companies [1]. The negative impact caused by work stress can be physiological, psychological, and behavior symptom [2]. Physiological symptoms lead to changes in metabolism, raise blood pressure, headaches, and cause heart attacks as a result of stress. From the psychological symptoms, stress can cause dissatisfaction.

This finding was supported by the opinion of that teachers who settle down will become excellent facilitators, teachers, and counselors [3]. They are also become an excellent role model as a person who has non-violent behavior, rarely experience stress, frustration and anger. Calmness is one of the very strong characteristics that a teacher must have. Without these characteristics, hard daily activities at school and other 
requirement that must be done by the teacher, will make them easier to experience stress, mental illness and be physical illness.

A principal must be able to respond the teacher stress at work environment in order to create a conducive work atmosphere. Therefore, the right strategy is needed to deal with the problem and avoid fluctuation that can hampering in achieving the school's goals, vision and mission. In line with this, considers that the principal is an important component in improving education quality. Therefore in school management, the principal is a prime mover in determining the policy towards school success and education at large [4].

Based on the result of preliminary field observation and from the complaint or confide in more than 10 teachers who experienced work stress. Researcher conducted interviews with several teachers in April 2020 and from these interviews the teacher felt had the burden of their role as a teacher.

In connection with the stress as the result of teacher's duty, the researcher conclude that the problems about principal's management strategies in dealing with teacher work stress and from the observation results, the main problems that affect pressure on teachers are job satisfaction and work stress. Based on this background, so the researcher needs to raise a thesis with entitled "The Principal Management Strategies in Deal with Work Stress of Teachers in Islamic Elementary School Faza Palembang"

\section{Method}

This research method is a qualitative approach. Qualitative research focuses in understanding the phenomena experienced by research subjects such as behavior, perception, motivation, action, etc., holistically, and descriptively in the form of words and language, in a special natural context and utilize various natural methods [5].

The type of research is descriptive. Descriptive research is generally carried out with the main objective to describe the facts systematically and object characteristics or subject under research accurately. The descriptive method is very useful for getting a variety of problems related to education and human behavior [6].

In obtaining the maximum possible data, in-depth observation and analysis required. The activity is pursued through a qualitative approach and will describe "The Principal Management Strategies in Deal with Work Stress of Teachers at Faza Islamic Elementary School Palembang"

\section{Results and Discussions}

The aim of this research is to describe an actual situation in the field regarding the strategies in dealing with work stress for teachers at Faza Islamic Elementary School Palembang. The presentation of the research results will be presented systematically according to qualitative descriptive research through descriptions and findings of researcher in the field.

This research was conducted to determine the school's strategies in dealing with work stress of teachers at Faza Islamic Elementary School Palembang, and from the results of researcher observations. The next step after the data presentation is describe in the result of research findings in all the cases that have been determined, the work stress experienced by teachers of Faza Islamic Elementary School Palembang and the principal's strategies in deal with teacher work stress.

The final step of this chapter is the discussion. In this section, the researcher describes the findings at Faza Islamic Elementary School Palembang related to the principal's strategies in managing work stress conflicts of teacher as described in the previous chapter. Furthermore, in discussion section, the findings are also described by positioning the results against the relationship and relevance of theory or previously research which is connect to the results of this research, and describe in an appropriate results.

Researcher describes the result of the observation and interview in field about Principal's Management Strategies in Dealing with teacher work stress at Faza Islamic Elementary School Palembang. This qualitative data will be described on the problem of teacher work stress, which is the strategies used by the principal in dealing with teacher work stress so that it does not give a negative effect on the implementation of teaching and learning activities at the Faza Islamic School Palembang.

\section{Conclusions}

Based on the results of collected data findings and has been through discussion and analysis about principal's management strategies in dealing with work stress of teachers at Faza Islamic Elementary School Teachers 
Palembang, it can be concluded that the management strategies of the principal at Faza Islamic Elementary School Palembang in dealing with teacher work stress are: 1) recognizing the symptom of teacher work stress, 2) identifying the emergence of work stress, 3) solve the problem as a result of work stress, then the principal deal with teacher work stress. This problem solving consist of three approaches, 1) through a personal approach, 2) a religious approach, 3) an official approach.

Work stress can be identified by three symptoms, they are physical symptoms, psychological symptoms, and social symptoms. The cause of stress occurred at Faza Islamic Elementary School Palembang because of tight deadlines, many teaching schedules and not being able to understand the characteristics of students.

One of the principal strategy that can be done to improve teacher's performance is to pay attention of work stress. However, the obstacle of the principal in dealing with teacher work stress at Faza Islamic Elementary School Palembang is that teachers who are experiencing work stress are not overt about express their problems and affect to poor performance.

Based on the conclusions which have been described above, the researcher wants to put forward any suggestions, 1) The principal of the school can dealing with teacher work stress at Faza Islamic Elementary School Palembang. The suggestion from the researcher is that the principal as the person in charge to always handle teacher's complaints that related to work stress at school. The principal can identify the problems of all teachers early so it does not spread to interfere with their performance. Then the principal expected to strengthen the strategy for dealing with work stress. 2) Teachers should always be a good role model for students and be able to provide useful knowledge for the improvement of the education world and be able to properly manage emotions and work stress as well. If there are problems that interfere with both thoughts and behavior, it expected does not spread widely, find out the solution using facilities and places that can help to solve their problems.

\section{References}

Munandar, A. S. 2006 Psikologi Industri dan Organisasi. Jakarta: UI-Press.

Robbins, stepen P. Perilaku Organisasi Konsep, Kontroversi, Aplikasi, Diterjemahkan oleh: Handayana Pujaatmaka. Jilid 1.Jakarta :Prenhallindo.

Paterson, Kathy. 2007. 55 Dilema Dalam Pengajaran. Jakarta: Grasindo.

Djafri, Novianty. 2017. Manajemen Kepemimpinan Kepala Sekolah.Yogyarta: Deepublish.

Moleong, Lexy J. 2011. Metode Penelitian Kualitatif. Bandung: Remaja Rosda Karya Remaja.

Sukardi.2004. Metodelogi Penelitian Pendidikan. Jakarta: Bumi Aksara. 